\title{
Correlates of Sexual Behaviors with Health Status and Health Perception in Chinese Adolescents: A Cross-Sectional Survey in Schools
}

\author{
WILLIAM C.W. WONG, M.B.Ch.B., M.R.C.G.P., ${ }^{1}$ ALBERT LEE, M.B., B.S., M.P.H., ${ }^{2}$ \\ and KWONG KA TSANG, M.D. ${ }^{2}$
}

\begin{abstract}
Sexual intercourse remains taboo among adolescents in a Chinese society such as Hong Kong. It is not openly discussed and little research has been done on its impact on health, although it carries serious risks of contracting sexually transmitted diseases (STDs)/HIV. In 1999, a cross-sectional, self-report survey on youth risk behaviors was carried out on 8382 students 15-18 years of age from 48 schools in Hong Kong. Three hundred seventy-seven $(4.69 \%)$ reported that they had had sexual intercourse. Among them, forced sex $(\mathbf{1 6 . 9 4 \% )}$ was common, most often happening to boys $(52.38 \%)$. They were more likely to have consulted doctors in the last month (odds ration [OR] 1.41 in boys $95 \%$ confidence interval [CI] 1.03, 1.94; OR 2.46 in girls 95\% CI 1.81, 3.30) and 6 months (OR 1.33 in boys 95\% CI 0.98, 1.78; OR 2.66 in girls $95 \%$ CI 1.80, 3.91). They also perceived poorer and deteriorating health. The sexually active female students were 6.70 times $(95 \%$ CI $4.65,9.66)$ more likely to attempt suicide than the other group and were more likely to take sick leaves (OR 3.56 in girls $95 \%$ CI 2.35, 5.41). Parental education and occupation, place of birth, and type of housing did not correlate in the initiation of sexual intercourse. The sexually experienced group reported worse physical and psychological health as well as health perception. Some of the characteristics and patterns identified in our study were quite different from the findings in the West but further studies are required to determine the reason for this.
\end{abstract}

\section{INTRODUCTION}

$\mathbf{T}$ HERE IS LITTLE DOUBT that first sexual intercourse remains an event of immense social and personal significance. Set against this, for adolescents in Hong Kong, are the cultural and social acceptance of premarital sexual behavior, social and individual expression of love and health in young people, and the influence of factors such as peer pressure and gender ideology.

${ }^{1}$ Department of Community and Family Medicine, ${ }^{2}$ Centre for Health Education and Health Promotion, School of Public Health, Kwong Ka Tsang MD, The Chinese University of Hong Kong, Prince of Wales Hospital, Shatin, Hong Kong. 
There is strong evidence that culture influences the frequency of risk behaviors ${ }^{1,2}$ and understanding variations and reasons behind them across different societies can provide insight into universal models of human behavior.

Lam et al. ${ }^{3}$ found that smoking and sexual intercourse was correlated with poorer psychological adjustments in the 13-18-year old age group but the extent and effects on both psychological and physical health is not known. From a practical point of view, the event possesses real health implications because it carries a risk of adverse outcomes such as unplanned pregnancy, sexually transmitted diseases (STDs), and infertility. ${ }^{4,5}$ This is particularly relevant with the rapid increase of sexually transmitted diseases (STDs)/HIV epidemics in the region. ${ }^{6,7}$ Moreover, many Western nations are becoming increasingly multicultural; thus, knowledge about the patterns of sexual and health-seeking behaviors in adolescent Chinese, if characteristics of those at greater risks are to be identified, would benefit health care providers so that more effective health promotion programs and service provisions can be arranged. ${ }^{8}$

In 1999, the Centre for Health Education and Health Promotion at the Chinese University of Hong Kong conducted a territory-wide health survey of more than 26,000 students 10-18 years of age. Using this data set, we looked at the sexual behaviors of the 15-18-year olds in Hong Kong. We wanted to see if there are differences in their perceptions of health, physical and mental health status, and medical consultation patterns in the sexually experienced and the inexperienced groups. The relationship of these variables to the gender of the students or number of partners was also examined.

\section{METHODS}

In the survey, 48 government-subsidized schools of different academic levels including prevocational training schools in different geographical areas throughout the territory were selected through a long-established school organization in Hong Kong.

The self-administered Hong Kong Youth Risk Behavior Survey (YRBS) was modified from similar survey devised by the Center for Disease Control and Prevention. ${ }^{9}$ The YRBS covers six health behavior categories: unintentional and intentional injuries; tobacco use; alcohol and other drug use; sexual behavior; unhealthy dietary behavior and physical activities. It also includes demographic data of the students, morbidity data and use of health care service. The questionnaire content was validated by face validity and pilot-tested in students from different schools of different age groups. Comments were also received from the teachers and the students in which special attention was drawn to the wording of the questionnaire, areas of difficulties experienced by students, and how to maintain the students' enthusiasm and perceived relevance of the exercise. Further details of the questionnaire and methodology have been described elsewhere. ${ }^{10}$

The research team visited all participating schools to explain to the teachers the objectives and details of the study, and discuss the questionnaire. Consent was sought from the parents of the students who would participate in the study. The research team members had briefed the students before and after the questionnaire, and the questionnaire was administered anonymously. Data were entered, cleaned, and analyzed using SPSS package (SPSS, Inc., Chicago, IL). Univariate analysis with health data as dependent variables and sexual intercourse as independent variables by $\chi^{2}$ statistics were conducted with $p$ values and odds ratios calculated. The local Clinical Research Ethics Committee approved this study.

\section{RESULTS}

A total of 8382 students between 15 and 18 years of age completed the questionnaire, of which 8039 were valid $(95.29 \%)$. Three hundred seventy-seven students $(4.69 \%)$ claimed to have had sexual intercourse (198 males and 179 females). Their age differentials are shown in Figure 1. Fifty-nine students said they had only ever had sex with one person (single partner) of whom 56 were boys, whereas 88 said they had had sex with more than one person (multiple partners), of whom 60 were boys. 


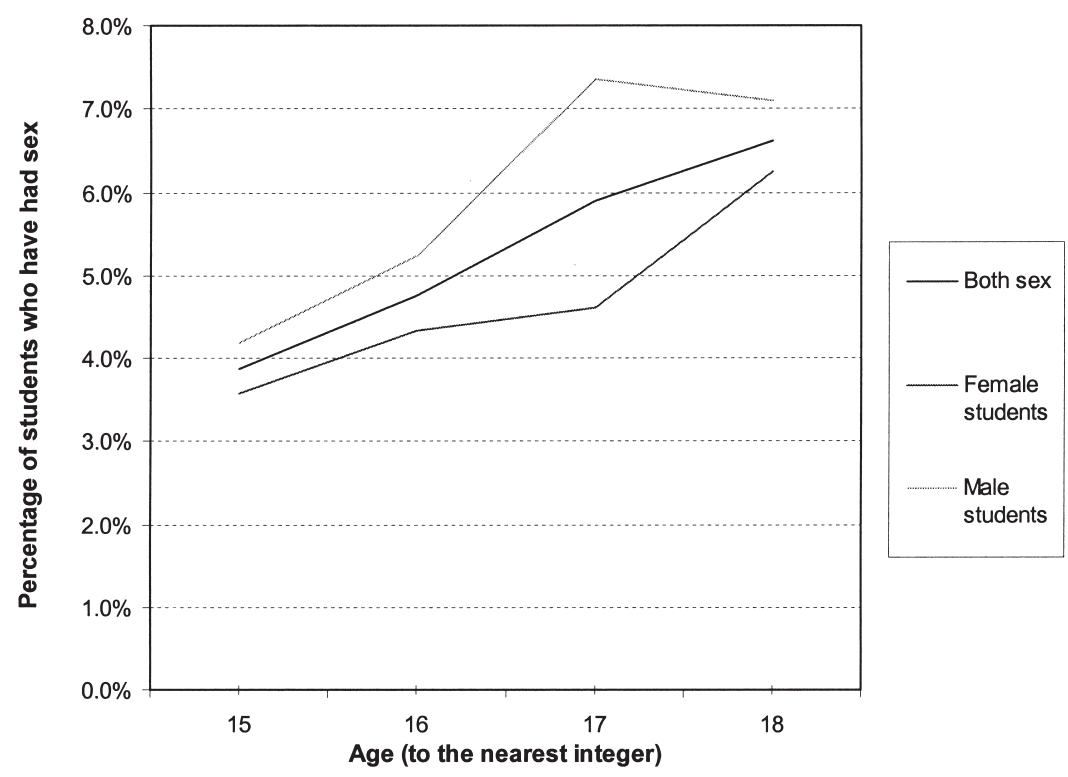

FIG. 1. Percentage of students in different age groups who have experienced sex.

Sixty-three students $(16.94 \%)$ claimed to have experienced forced sex without consent; more than half were boys. Violent behavior was more common among the sexually experienced group in both genders: $15.17 \%$ of sexually experienced girls had been involved in physical fights in the last 12 months as opposed to $2.65 \%$ of the virgins $(p<0.0001)$. In boys, the figures were $42.56 \%$ and $13.15 \%$ respectively $(p<0.0001)$ (Table 1). However, there were no statistical differences between the two groups in terms of parental education levels, occupations, or the types of housing in which they lived. In addition, whether one was born in Hong Kong or immigrated from elsewhere did not contribute to this behavior (Table 1).

Students who had had sexual intercourse were more likely to have consulted a doctor in the last month (odds ration [OR] 1.41 95\% (confidence interval [CI] 1.03, 1.94 in males and 2.46 $95 \%$ CI 1.81, 3.30 in females) and the 5 months prior to that (OR 1.33 95\% CI 0.98, 1.78 and 2.66 $95 \%$ CI 1.80, 3.91 in male and female students, respectively) compared to those with no sexual experience (Table 2). The consultations were more likely of general and unspecific nature $(2.5095 \%$ CI $1.61,3.89)$ or related to the digestive (OR 4.29 95\% CI 2.82, 6.52), neurologic (OR $2.4995 \%$ CI 1.48, 4.21), or respiratory systems (OR 1.77 95\% CI 1.26, 2.47) in female students but only significant (OR 2.38 95\% CI 1.17, 4.83) in neurologic system in male students. Few students from either group sought advice related to sexual issues such as urology, pregnancy, family planning, male/female genital systems or psychological/social problems. There was no statistical significant association between sexual intercourse and uptake of preventive services such as vaccinations in the two groups. No statistical difference in the number of consultations or self-medications between the groups with single or multiple partners was observed (Table 3).

In terms of perception of health, those who have had sex were more likely to perceive poorer health, particularly in the female students (Table 4). More students in the sexually experienced group as opposed to the female virgins $(1.7095 \%$ CI 1.26, 2.31) stated that their health was fair/poor. This was reconfirmed by an opposite statement: "I am very healthy at the moment" (OR 1.83 95\% CI 1.25, 2.66 in female students). The female sexually experienced students disagreed that their health was similar to their peers (OR 2.15 95\% CI 1.39, 3.31) and they also felt that they became sick easily (OR 1.46 95\% CI 1.02, 2.09).

Those who had had sex were more likely and more often to have physical or mental health problems, had affected their social life for the previous 4 weeks (OR 1.56 95\% CI 1.02, 2.38 and $1.6995 \%$ CI 1.15, 2.49 in male and female 
Table 1. Comparison of Demographic and Sexual Characteristics in Sexually Experienced and Virgin Groups

\begin{tabular}{|c|c|c|c|c|c|c|}
\hline \multirow[b]{2}{*}{ Characteristics of the students } & \multicolumn{3}{|c|}{ Male } & \multicolumn{3}{|c|}{ Female } \\
\hline & No. & $\begin{array}{l}\text { No. (\%) who had } \\
\text { intercourse }\end{array}$ & $\mathrm{p}$ value & No. & $\begin{array}{l}\text { No. (\%) who had } \\
\text { intercourse }\end{array}$ & $\mathrm{p}$ value \\
\hline \multicolumn{7}{|l|}{ Forced sex without consent } \\
\hline Yes & 194 & $33(17.01)$ & & 178 & $30(16.85)$ & \\
\hline \multicolumn{7}{|l|}{ Engaged in physical violence } \\
\hline Yes & 195 & $83(42.56)$ & & 178 & 27 (15.17) & \\
\hline No & 3582 & 471 (13.15) & $<0.001$ & 4036 & $107(2.65)$ & $<0.001$ \\
\hline \multicolumn{7}{|l|}{$\begin{array}{l}\text { Father's education level } \\
\text { (secondary or above) }\end{array}$} \\
\hline Yes & 142 & $77(54.23)$ & & 153 & $83(54.25)$ & \\
\hline No & 2838 & $1633(57.54)$ & 0.436 & 3431 & $2038(59.40)$ & 0.205 \\
\hline \multicolumn{7}{|l|}{$\begin{array}{l}\text { Mother's education level } \\
\text { (secondary or above) }\end{array}$} \\
\hline Yes & 151 & $72(47.68)$ & & 157 & $78(49.68)$ & \\
\hline No & 2893 & 1477 (51.05) & 0.419 & 3540 & $1841(52.01)$ & 0.568 \\
\hline \multicolumn{7}{|c|}{ Father's occupation (class II or above) } \\
\hline Yes & 148 & $39(26.35)$ & & 148 & $38(25.68)$ & \\
\hline No & 2942 & $677(23.01)$ & 0.347 & 3358 & $816(24.30)$ & 0.703 \\
\hline \multicolumn{7}{|c|}{ Mother's occupation (class II or above) } \\
\hline Yes & 83 & $11(13.25)$ & & 73 & $13(17.81)$ & \\
\hline No & 1457 & 235 (16.13) & 0.487 & 1597 & 295 (18.47) & 0.886 \\
\hline \multicolumn{7}{|l|}{ Housing: public estate } \\
\hline Yes & 193 & $97(50.26)$ & & 177 & $81(45.76)$ & \\
\hline No & 3566 & $1626(45.60)$ & 0.490 & 4012 & $1721(42.90)$ & 0.602 \\
\hline \multicolumn{7}{|l|}{ Home-ownership scheme } \\
\hline Yes & 193 & $20(10.36)$ & & 177 & 19 (10.73) & \\
\hline No & 3566 & $380(10.66)$ & 0.490 & 4012 & $355(8.85)$ & 0.602 \\
\hline \multicolumn{7}{|l|}{ Private housing } \\
\hline Yes & 193 & $62(32.12)$ & & 177 & $58(32.77)$ & \\
\hline No & 3566 & $1203(33.74)$ & 0.490 & 4012 & $1505(37.51)$ & 0.602 \\
\hline \multicolumn{7}{|l|}{ Rented private housing } \\
\hline Yes & 193 & $14(7.25)$ & & 177 & $17(9.60)$ & \\
\hline No & 3566 & $326(9.14)$ & 0.490 & 4012 & 406 (10.12) & 0.602 \\
\hline \multicolumn{7}{|l|}{ Others } \\
\hline Yes & 193 & $0(0.00)$ & & 177 & $2(1.13)$ & \\
\hline No & 3566 & $31(0.87)$ & 0.490 & 4012 & $25(0.62)$ & 0.602 \\
\hline \multicolumn{7}{|l|}{ Born outside Hong Kong } \\
\hline Yes & 195 & $47(24.10)$ & & 179 & $29(16.20)$ & \\
\hline No & 3576 & $725(20.27)$ & 0.197 & 4027 & $841(20.88)$ & 0.130 \\
\hline \multicolumn{7}{|l|}{ New Immigrants } \\
\hline Yes & 195 & $13(6.67)$ & & 179 & $16(8.94)$ & \\
\hline No & 3576 & $252(7.05)$ & 0.840 & 4027 & $304(7.55)$ & 0.493 \\
\hline
\end{tabular}

students, respectively). The sexually experienced female students were more likely to take 3 or more days of sick leave (OR 3.56 95\% CI $2.35,5.41)$, and report feeling sad and hopeless almost everyday for 2 weeks or more in a row, which had severely affected their usual activities during the previous 12 months (OR 2.64 $95 \%$ CI 1.91, 3.64). Sexually experience students had higher odds of considering suicide (OR $2.4795 \%$ CI 1.97, 3.10), planning for suicide (OR 3.00 95\% CI 2.25, 3.99), and attempting suicide (OR 5.29 95\% CI 3.93, 7.13), particularly female students (OR 3.19, OR 3.1, OR 6.7, respectively).
No statistical significance was observed in terms of medical consultation, emotional problems, and perceived health status between those with one partner and those with multiple partners.

\section{DISCUSSION}

In our sample, the number of 15- to 18-year old students who admitted having had sexual intercourse was much lower than that in Western countries but was consistent with previous 


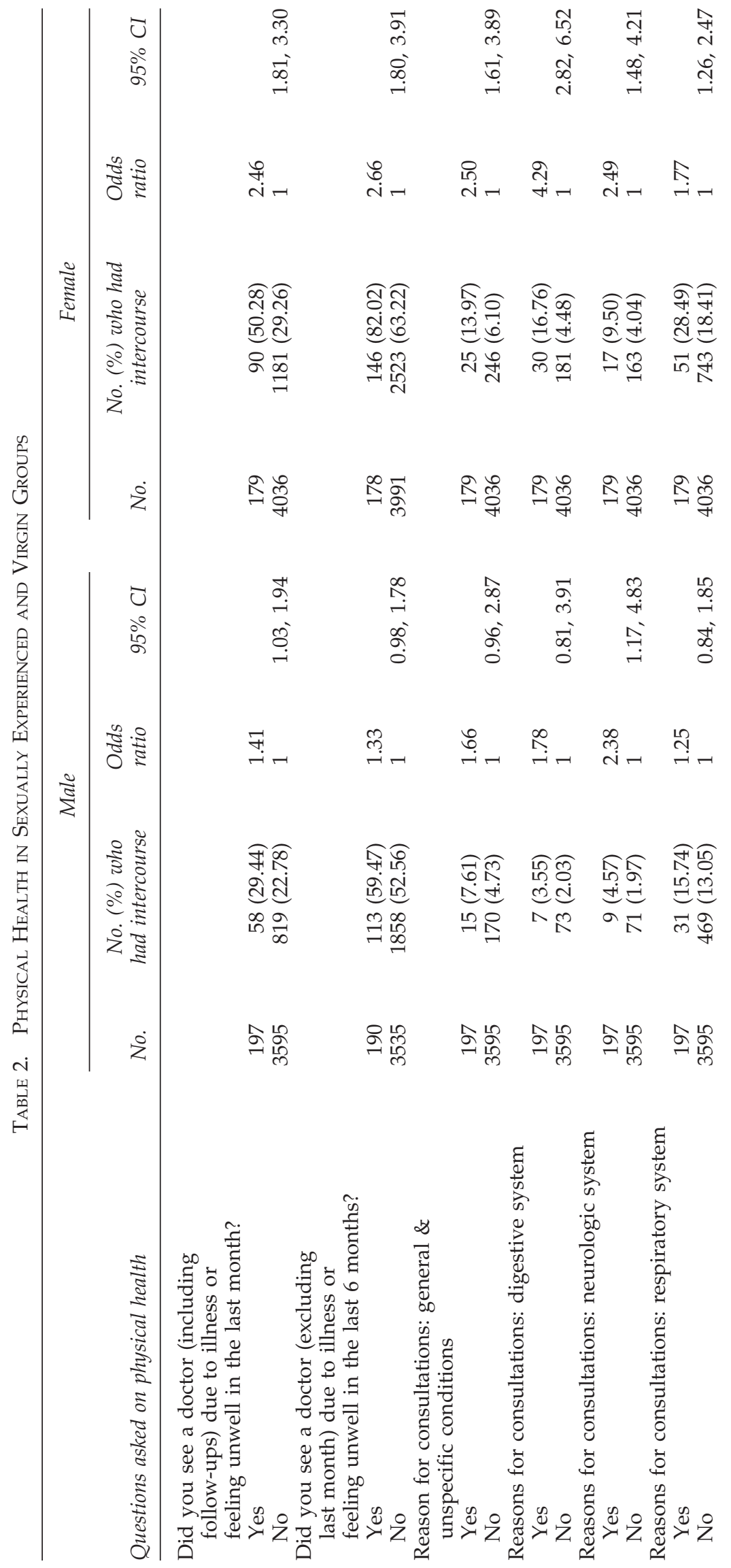




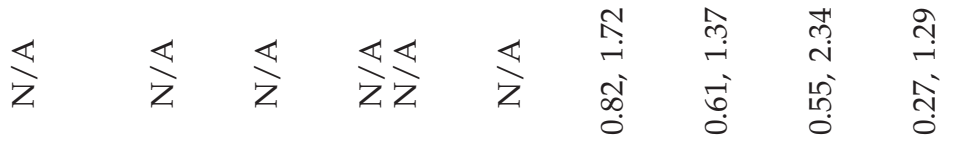

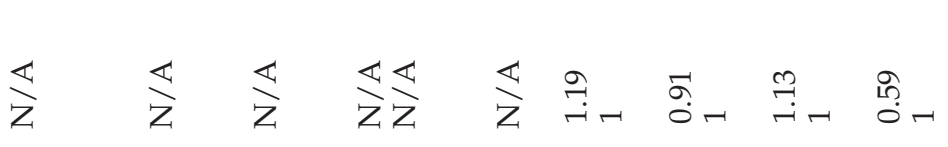

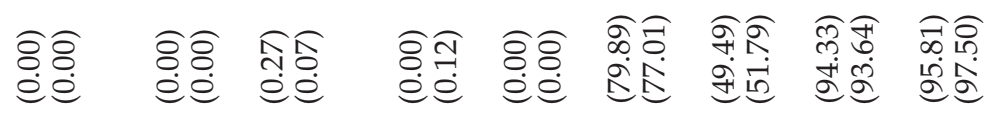

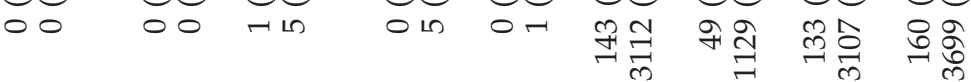

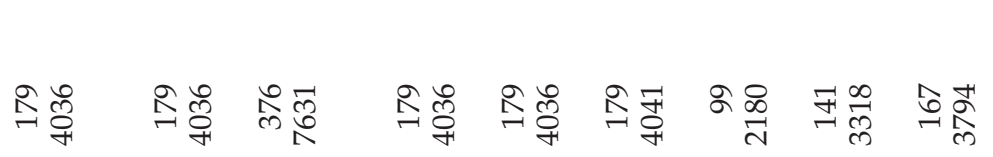

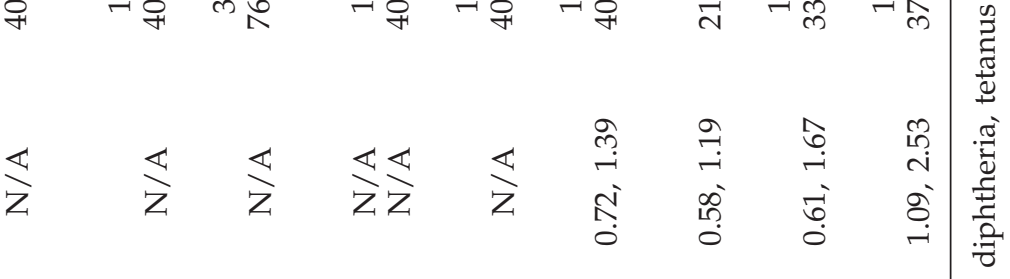

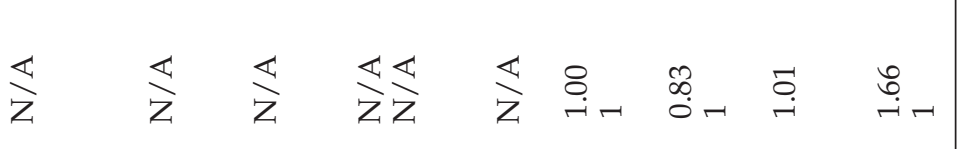

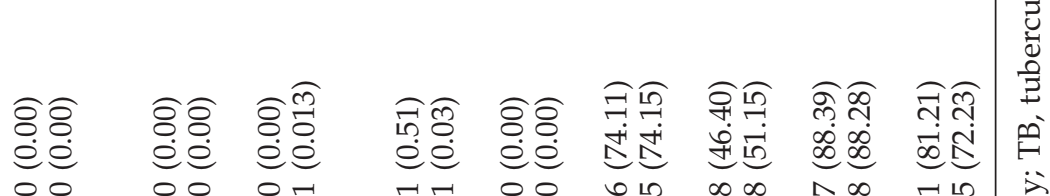

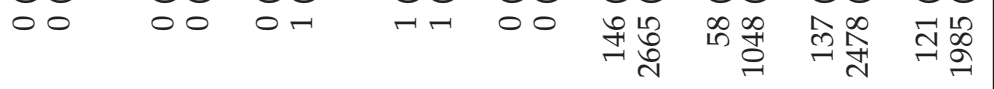

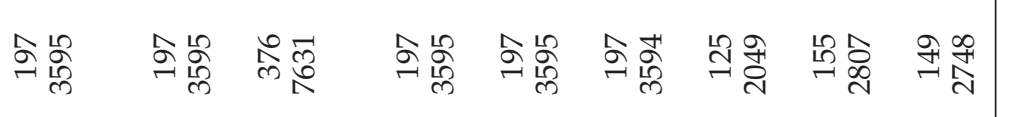


Table 3. Health of the Sexually Experienced with One Partner and Multiple Partners

\begin{tabular}{|c|c|c|c|c|c|c|}
\hline \multirow[b]{2}{*}{ Questions asked in the sexually experienced: } & \multicolumn{2}{|c|}{ Single partner } & \multicolumn{4}{|c|}{ Multiple partners } \\
\hline & No. & $\begin{array}{l}\text { No. }(\%) \text { who had } \\
\text { single partner }\end{array}$ & No. & $\begin{array}{l}\text { No. }(\%) \text { who had } \\
\text { multiple partners }\end{array}$ & $\begin{array}{l}\text { Odds } \\
\text { ratio }\end{array}$ & $95 \% C I$ \\
\hline Male & 92 & $31(33.70)$ & 92 & $61(66.30)$ & & \\
\hline Female & 62 & $30(48.39)$ & 62 & $31(48.39)$ & & \\
\hline $\begin{array}{l}\text { Did you see a doctor (including follow- } \\
\text { ups) due to illness or feeling unwell } \\
\text { in the last month? YES }\end{array}$ & 58 & $24(41.38)$ & 88 & $36(40.91)$ & 0.98 & $0.50,1.92$ \\
\hline $\begin{array}{l}\text { Did you see a doctor (excluding last } \\
\text { month) due to illness or feeling unwell } \\
\text { in the last } 6 \text { months?: YES }\end{array}$ & 58 & $40(68.97)$ & 84 & $63(75)$ & 1.35 & $0.64,2.84$ \\
\hline $\begin{array}{l}\text { In the last } 6 \text { months, did you take any } \\
\text { medicine without doctor's } \\
\text { instruction?: YES }\end{array}$ & 58 & $33(56.90)$ & 82 & $38(46.34)$ & 0.65 & $0.33,1.29$ \\
\hline If yes to the above, how many times? & $\begin{array}{l}\text { Mean: } \\
3.36\end{array}$ & & $\begin{array}{c}\text { Mean: } \\
5.82\end{array}$ & & & \\
\hline $\begin{array}{l}\text { Overall, how do you grade your health } \\
\text { statues? Fair to Poor }\end{array}$ & 57 & $21(36.84)$ & 86 & $25(29.07)$ & 0.70 & $0.35,1.43$ \\
\hline $\begin{array}{l}\text { I get sick easier than others. Agree to } \\
\text { strongly agree }\end{array}$ & 45 & $7(15.56)$ & 66 & $17(25.76)$ & 1.88 & $0.71,5.00$ \\
\hline $\begin{array}{l}\text { I am as healthy as others: disagree to } \\
\text { strongly disagree }\end{array}$ & 47 & $6(12.77)$ & 67 & $9(13.43)$ & 1.06 & $0.35,3.21$ \\
\hline $\begin{array}{l}\text { I expect my health is getting worse: } \\
\text { agree to strongly agree }\end{array}$ & 55 & $17(30.91)$ & 36 & $7(19.44)$ & 1.85 & $0.68,5.06$ \\
\hline $\begin{array}{l}\text { I am very healthy at the moment: } \\
\text { disagree to strongly disagree }\end{array}$ & 43 & $11(25.58)$ & 68 & $15(22.06)$ & 0.82 & $0.34,2.01$ \\
\hline $\begin{array}{l}\text { In the past } 4 \text { weeks, your health or } \\
\text { emotional problems that affected your } \\
\text { usual social activities with your family, } \\
\text { friends or other people?: } \\
\text { considerable to severely }\end{array}$ & 52 & $12(23.08)$ & 83 & 19 (22.89) & 0.99 & $0.43,2.26$ \\
\hline $\begin{array}{l}\text { In the past } 4 \text { weeks, how often did your } \\
\text { health or emotional problems affect } \\
\text { your usual social activities?: } \\
\text { sometimes to always }\end{array}$ & 52 & $15(28.85)$ & 81 & $21(25.93)$ & 0.86 & $0.40,1.88$ \\
\hline $\begin{array}{l}\text { In the past } 6 \text { months, have you ever } \\
\text { taken } 3 \text { days or more sick leave from } \\
\text { school: YES }\end{array}$ & 54 & $9(16.67)$ & 83 & $11(13.25)$ & 0.76 & $0.29,1.99$ \\
\hline $\begin{array}{l}\text { In the past } 12 \text { months, did you feel sad } \\
\text { and hopeless almost everyday for } 2 \\
\text { weeks or more that stopped you from } \\
\text { usual social activities: YES }\end{array}$ & 59 & $13(22.03)$ & 87 & $30(34.48)$ & 1.86 & $0.87,3.97$ \\
\hline $\begin{array}{l}\text { In the past } 12 \text { months, did you ever } \\
\text { consider suicide?: YES }\end{array}$ & 59 & $22(37.29)$ & 85 & $34(40)$ & 1.12 & $0.57,2.22$ \\
\hline $\begin{array}{l}\text { In the past } 12 \text { months, have you planned } \\
\text { a suicide?: YES }\end{array}$ & 59 & $9(15.25)$ & 86 & $21(24.42)$ & 1.80 & $0.76,4.26$ \\
\hline $\begin{array}{l}\text { In the past } 12 \text { months, did you actually } \\
\text { attempt suicide?: YES }\end{array}$ & 57 & $10(17.54)$ & 85 & $20(23.53)$ & 1.45 & $0.62,3.37$ \\
\hline
\end{tabular}

CI, confidence interval.

findings in Hong Kong. ${ }^{11-16}$ This pattern can be explained by Arnett's model of socialization ${ }^{2}$ : Adolescents from cultures in which individualism and self-expression are more valued tend to engage in higher risk behavior compared to a Chinese society where obedience, conformity, and respect for social order is emphasized. What is unexplained is that our data show social class and housing have no correlation in the onset of this behavior in Hong Kong, which defies Lowry's conclusion that health risk behaviors among adolescents are inversely proportional to their socioeconomic status. ${ }^{17-19}$ One of the authors (A.L.) suggests that school environment rather than parental background has a more significant influence on 
Table 4. Health Perception in the Sexually Experienced and Virgin Groups

\begin{tabular}{|c|c|c|c|c|c|c|c|c|}
\hline \multirow[b]{2}{*}{ Questions asked on health perception } & \multicolumn{4}{|c|}{ Male } & \multicolumn{4}{|c|}{ Female } \\
\hline & No. & $\begin{array}{l}\text { No. (\%) } \\
\text { who had } \\
\text { intercourse }\end{array}$ & $\begin{array}{l}\text { Odds } \\
\text { ratio }\end{array}$ & $95 \% C I$ & No. & $\begin{array}{c}\text { No. }(\%) \\
\text { who had } \\
\text { intercourse }\end{array}$ & $\begin{array}{l}\text { Odds } \\
\text { ratio }\end{array}$ & $95 \% C I$ \\
\hline \multicolumn{9}{|l|}{$\begin{array}{l}\text { Overall, how do you grade your } \\
\text { health status?: Fair to Poor }\end{array}$} \\
\hline Yes & 193 & $39(20.21)$ & 1.12 & & 178 & $79(44.38)$ & 1.70 & \\
\hline No & 3587 & $661(18.43)$ & 1 & $0.78,1.61$ & 4032 & $1286(31.89)$ & 1 & $1.26,2.31$ \\
\hline \multicolumn{9}{|l|}{$\begin{array}{l}\text { I get sick easier than others: Agree } \\
\text { to strongly agree }\end{array}$} \\
\hline Yes & 153 & $26(16.99)$ & 1.07 & & 141 & $41(29.01)$ & 1.46 & \\
\hline No & 2881 & $463(16.07)$ & 1 & $0.69,1.65$ & 3159 & $806(25.51)$ & 1 & $1.02,2.09$ \\
\hline \multicolumn{9}{|l|}{$\begin{array}{l}\text { I am as healthy as others: Disagree } \\
\text { to strongly disagree }\end{array}$} \\
\hline Yes & 154 & $13(8.44)$ & 1.05 & & 134 & $28(20.90)$ & 2.15 & \\
\hline No & 2804 & $227(8.10)$ & 1 & $0.58,1.88$ & 2949 & $323(10.95)$ & 1 & $1.39,3.31$ \\
\hline \multicolumn{9}{|l|}{$\begin{array}{l}\text { I expect my health is getting worse: } \\
\text { Agree to strongly agree }\end{array}$} \\
\hline Yes & 128 & $27(21.09)$ & 1.78 & & 105 & $25(23.81)$ & 1.39 & \\
\hline No & 2300 & 301 (13.09) & 1 & $1.14,2.76$ & 2423 & 445 (18.37) & 1 & $0.88,2.20$ \\
\hline \multicolumn{9}{|l|}{$\begin{array}{l}\text { I am very healthy at the moment: } \\
\text { Disagree to strongly disagree }\end{array}$} \\
\hline Yes & 150 & $21(14)$ & 1.45 & & 138 & $41(29.71)$ & 1.83 & \\
\hline No & 2922 & $295(10.10)$ & 1 & $0.90,2.34$ & 3127 & $588(18.80)$ & 1 & $1.25,2.66$ \\
\hline
\end{tabular}

CI, confidence interval.

lifestyle and behavior of students in Hong Kong. ${ }^{20}$

A significant number of students in the sexually experienced group claimed to have been forced to undergo sex involuntarily. Similar associations between sexual abuse and suicide attempts were observed in adolescents in the United States but to a much lesser extent. The loss of self-esteem, and feelings of guilt and helplessness seen in this group may contribute to the overall poor psychological health and health perceptions. Because these issues are not usually discussed openly in the Asian culture, ${ }^{21}$ the lack of proper channels allowing them to reprimand extreme ways such as thoughts of suicide thought and suicide attempts. An equally high proportion of nonconsensual sex is noted in our male students and this demands further exploration.

Those who had sex reported worse physical and psychological health, and had poorer perception of their own health. However, in a cross-sectional survey, the reasons for having sexual intercourse in this age group must remain speculative because ill health may influence the decision to have sex while the burden of social and cultural pressure may influence those who have had sex. One thing was clear in the sexually experienced group of our sample: they were desperately unhappy. Many had taken time off from school or had their social life negatively affected. Some had even resorted to ending their own lives. It was reasonable to think that many sought comfort and care from intimate relationships, which would put them at higher risks of STDs and HIV. Whether sexual behavior can have such serious psychological and physical consequences in this age group or whether this group is a selfselected one with more underlying psychological and social problems, thus engaging in sexual relationships as a means of escape demands further investigation.

In the questionnaire, the students were asked to record the reasons for and diagnosis at each consultation in the previous 1 and 5 months. We found that consultation rates in the sexually experienced group were high and the nature of their consultations was related to anything but sexual issues. No STD was ever mentioned by our sample and only one person $(1 / 376)$ in the sexually experienced group ever 
Table 5. Psychological Health of the Sexually Experienced and Virgin Groups

\begin{tabular}{|c|c|c|c|c|c|c|c|c|}
\hline \multirow[b]{2}{*}{$\begin{array}{l}\text { Questions asked on } \\
\text { psychological health }\end{array}$} & \multicolumn{4}{|c|}{ Male } & \multicolumn{4}{|c|}{ Female } \\
\hline & No. & $\begin{array}{l}\text { No. }(\%) \\
\text { who had } \\
\text { intercourse }\end{array}$ & $\begin{array}{l}\text { Odds } \\
\text { ratio }\end{array}$ & $95 \% C I$ & No. & $\begin{array}{l}\text { No. }(\%) \\
\text { who had } \\
\text { intercourse }\end{array}$ & $\begin{array}{l}\text { Odds } \\
\text { ratio }\end{array}$ & $95 \% C I$ \\
\hline \multicolumn{9}{|c|}{$\begin{array}{l}\text { In the past } 4 \text { weeks, your health } \\
\text { or emotional problems that } \\
\text { affected your usual social } \\
\text { activities with your family, } \\
\text { friends or other people?: } \\
\text { Considerable to Severely }\end{array}$} \\
\hline Yes & 179 & 27 (15.08) & 1.56 & & 164 & $35(21.34)$ & 1.69 & \\
\hline No & 3440 & $352(10.23)$ & 1 & $1.02,2.38$ & 3918 & $541(13.81)$ & 1 & $1.15,2.49$ \\
\hline \multicolumn{9}{|c|}{$\begin{array}{l}\text { In the past } 4 \text { weeks, how often } \\
\text { did your health or emotional } \\
\text { problems affect your usual } \\
\text { social activities?: } \\
\text { Sometimes to Always }\end{array}$} \\
\hline Yes & 176 & $41(23.30)$ & 1.74 & & 164 & 38 (23.17) & 1.43 & \\
\hline No & 3441 & $512(14.88)$ & 1 & $1.21,2.50$ & 3919 & $683(17.43)$ & 1 & $0.99,2.07$ \\
\hline \multicolumn{9}{|c|}{$\begin{array}{l}\text { In the past } 6 \text { months, have you } \\
\text { ever taken } 3 \text { days or more } \\
\text { sick leaves from school?: }\end{array}$} \\
\hline Yes & 192 & $17(8.85)$ & 1.48 & & 169 & 30 (17.75) & 3.56 & \\
\hline No & 3511 & $216(6.15)$ & 1 & $0.88,2.48$ & 3975 & $227(5.71)$ & 1 & $2.35,5.41$ \\
\hline \multicolumn{9}{|c|}{$\begin{array}{l}\text { In the past } 12 \text { months, did you } \\
\text { feel sad and hopeless almost } \\
\text { everyday for } 2 \text { weeks or more } \\
\text { that stopped you from usual } \\
\text { social activities: }\end{array}$} \\
\hline Yes & 197 & $51(25.89)$ & 2.19 & & 178 & 59 (33.15) & 2.64 & \\
\hline No & 3594 & 495 (13.77) & 1 & $1.57,3.05$ & 3399 & $639(18.80)$ & 1 & $1.91,3.64$ \\
\hline \multicolumn{9}{|c|}{$\begin{array}{l}\text { In the past } 12 \text { months, did you } \\
\text { ever consider suicide? }\end{array}$} \\
\hline Yes & 195 & $41(20.87)$ & 2.10 & & 174 & $81(46.55)$ & 3.19 & \\
\hline No & 3534 & 397 (11.23) & 1 & $1.47,3.02$ & 3986 & $855(21.45)$ & 1 & $2.35,4.34$ \\
\hline \multicolumn{9}{|c|}{$\begin{array}{l}\text { In the past } 12 \text { months, have you } \\
\text { planned a suicide?: }\end{array}$} \\
\hline Yes & 194 & $26(13.40)$ & 3.14 & & 175 & 37 (21.14) & 3.10 & \\
\hline No & 3531 & $166(4.70)$ & & $2.02,4.88$ & 3982 & $317(7.96)$ & 1 & $2.12,4.54$ \\
\hline \multicolumn{9}{|c|}{$\begin{array}{l}\text { In the past } 12 \text { months, did you } \\
\text { actually attempt suicide?: }\end{array}$} \\
\hline Yes & 193 & $16(8.30)$ & 4.17 & & 173 & 46 (26.59) & 6.70 & \\
\hline No & 3533 & $75(2.12)$ & 1 & $2.38,7.30$ & 3980 & $204(5.13)$ & 1 & $4.65,9.66$ \\
\hline
\end{tabular}

CI, confidence interval.

consulted a doctor for a psychological issue over the previous month and 6 months. This might reflect the unacceptability and stigma associated with such behavior ${ }^{22}$ or simply be because of poor awareness in this group. Many STDs can remain subclinical for many years and increase their spread in the current epidemic. $^{23-25}$

Undoubtedly, the STDs/HIV crisis brings new challenges for all people in Hong Kong, especially the young. To prevent these diseases effectively, sex education should be targeted at high-risk groups and our findings showed that the sexually experienced group might perceive themselves to have and present with poorer psychological and physical health. Schools should be alerted when their students report sick frequently or have had suicidal attempts. On the medical side, doctors do not seem to be the first point of contact for this age group. Perceived difficulty in getting an appointment, fear of embarrassment, feeling able to confide 
in a primary care doctor, and perception of adequate time being given in the consultation was associated with lower consultation rates with family doctors for gynecological problems and contraception by the adolescents in the United Kingdom. ${ }^{26}$ Whether these are the major reasons for the low consultation rates in Hong Kong and how we can change this perception needs further exploration. Nevertheless, physicians should have more training on recognition of symptoms and signs of mental health problems, and be given clear guidelines as to where and when to refer these patients when dealing with these situations. Enquiries into close relationships in a skillful way can be revealing. For example, a doctor should be more alert when an adolescent comes to consult about contraception; screening for depression and assessment for suicidal risk may be included to detect an undisclosed and unrecognized psychological disturbance.

\section{ACKNOWLEDGMENTS}

We would like to express our sincere thanks to Quality Education Fund of the Hong Kong SAR Government for funding support of the Healthy School Program, and also all the participating schools for their collaboration.

Funding provided by Quality Education Fund, Hong Kong SAR Government.

\section{REFERENCES}

1. Arnett J, Jensen LA. Socialization and risk behavior in two countries: Denmark and the United States. Youth Soc 1999;6:3-22.

2. Arnett J. Reckless behaviors in adolescence: A development perspective. Dev Rev 1994;12:339-373.

3. Lam TH, Stewart SM, Ho LM. Smoking and high-risk sexual behavior among young adults in Hong Kong. J Behav Med 2001;25;503-518.

4. Wellings K, Nanchahal K, Macdowall W, et al. Sexual behavior in Britain: early heterosexual experience. Lancet 2001;358:1843-1850.

5. Fenton KA, Korovessis C, Johnson AM, et al. Sexual behavior in Britain: Reported sexually transmitted infections and prevalent genital Chlamydia trachomatis infection. Lancet 2001;358:1851-1854.

6. Gusky O, Liu H, Johnston M. HIV/AIDS in China: 1990-2001. AIDS Behav 2002:6:381-393.
7. van den Hoek A, Yuliang F, Dukers NH, et al. High prevalence of syphilis and other sexually transmitted diseases among sex workers in China: Potential for fast spread of HIV. AIDS 2001;15:753-759.

8. Jones EF, Forrest JD, Goldman N, et al. Teenage pregnancies in developed countries: determinants and policy implications. Fam Plann Prospect 1985; 4:9-18.

9. Kolbe LJ, Kann L, Collins JL. Overview of the Youth Risk Behavior Surveillance System. Public Health Rep 1993;108(Suppl 1):2-10.

10. Lee A, Tsang KK, Lee SH, To CY. Older school children are not necessarily healthier: An analysis of medical consultation pattern of school children from a territory-wide School Health Surveillance. Public Health 2001;115:30-37.

11. Lam TH, Stewart SM, Ho LM. Prevalence and correlates of smoking and sexual activity among Hong Kong adolescents. J Adolesc Health 2001;29:352358.

12. Warren CW, Santelli JS, Everett SA, et al. Sexual behavior among U.S. high school students, 1990-1995. Fam Plann Perspect 1998;30:170-172, 200.

13. Aten MJ, Siegel DM, Enaharo M, Auinger P. Keeping middle school students abstinent: Outcomes of a primary prevention intervention. J Adolesc Health 2002; 31:70-78.

14. Edgardh K. Sexual behavior and early coitarche in a national sample of 17-year-old Swedish girls. Sex Transm Infect 2000;76:98-102.

15. Davoli M, Perucci CA, Sangalli M, Brancato G, Dell'Uomo G. Reliability of sexual behavior data among high school students in Rome. Epidemiology 1992;3: 531-535.

16. Weisberg E, North P, Buxton M. Sexual activity and condom use in high school students. Med J Aust 1992;156:612-613.

17. Forman D, Chilvers C. Sexual behavior of young and middle aged men in England and Wales. BMJ 1989;298:1137-1142.

18. West P, Wight D, MacIntyre S. Heterosexual behavior of the 18 year olds in the Glasgow area. J Adolesc 1993;16:367-396.

19. Lowry R, Kann L, Collins J, Kolbe LJ. The effect of socio-economic status on chronic disease risk behaviors among US adolescents. JAMA 1996;76:792-797.

20. Lee A, Tsang KK, Lee SH, To CY. An YRBS at Alternative High Schools and Main Stream School in Hong Kong. J Sch Health 2001;71:443-447.

21. Bulbeck C. Sexual dangers. Chinese women's experiences in these cultures-Beijing, Taipei and Hong Kong. Women's Studies International Forum 1994;17: 95-103.

22. Fortenberry JD. Health seeking behavior related to sexually transmitted diseases among adolescents. Am J Public Health 1997;87:417-420.

23. Jacobs NF, Kraus SF. Gonococcal and nongonococcal urethritis in men: Clinical and laboratory differentiation. Ann Intern Med 1975;82:7-12.

24. Handsfield HH, Lipman TO, Harnisch JP, et al. 
Asymptomatic gonorrhea in men: Diagnosis, natural course, prevalence and significance. N Engl J Med 1974;290:117-123.

25. Oriel JD, Povris P, Reeve P, et al. Chlamydial infections of the cervix. Br J Vener Dis 1974;50:1-16.

26. Churchill R, Allen J, Denman S, et al. Do the attitudes and beliefs of young teenagers towards general practice influence actual consultation behavior? Br J Gen Pract 2000;50:953-957.
Address reprint requests to: Dr. William Wong, M.B., Ch.B., M.R.C.G.P. Department of Community and Family Medicine The Chinese University of Hong Kong Prince of Wales Hospital Shatin, Hong Kong

E-mail: cwwong@cuhk.edu.hk 